\title{
Marketing Public Relations Strategies to Develop Brand Awareness of Coffee Products
}

\author{
Tien-Chin Wang ${ }^{1}$, Muhammad Ghalih ${ }^{1,2}$, Glen Andrew Porter ${ }^{3, *}$ \\ ${ }^{1}$ Dept. of International Business, National Kaohsiung University of Applied Sciences, Kaohsiung, Taiwan \\ ${ }^{2}$ State Polytechnic Tanah Laut, Pelaihari, Indonesia \\ ${ }^{3}$ Dept. of Electronic Engineering, National Kaohsiung University of Applied Sciences, Kaohsiung, Taiwan
}

\section{Email address:}

tcwang@kuas.edu.tw (Tien-Chin Wang), ghalih@politala.ac.id (M. Ghalih), gaporter1@kuas.edu.tw (G. A. Porter)

${ }^{*}$ Corresponding author

\section{To cite this article:}

Tien-Chin Wang, Muhammad Ghalih, Glen Andrew Porter. Marketing Public Relations Strategies to Develop Brand Awareness of Coffee Products. Science Journal of Business and Management. Vol. 5, No. 3, 2017, pp. 116-121. doi: 10.11648/j.sjbm.20170503.15

Received: March 31, 2017; Accepted: April 22, 2017; Published: May 4, 2017

\begin{abstract}
These days' technologies offer new channels to reach public and market, the convergence between the various communications fields increases which is in marketing public relations strategies used to for developing a brand awareness the product such as coffee products. This paper likewise provides a solution to develop a brand awareness via media store sellers who might help the company to promote their products in light of consumer behavior. In this study, one hundred and fifteen questionnaires, on facilities available in the society, and technology distributed online, and it focuses on generations millennial in Taiwan. The purpose of the survey will focus on coffee products from Indonesia which is called Coffindo Nusantara from Coffindo Company.
\end{abstract}

Keywords: Brand Awareness, Coffee Products, Marketing, Public Relations Strategies

\section{Introduction}

The aim of the study is to propose methods to create public relations and marketing strategies towards developing brand awareness of coffee products from Indonesia into the international market, such as in Taiwan.

Further, in business world branding is the most powerful marketing weapon, and in public relations distinctive management functions which help establish and maintain mutual lines of communication between the company and the consumer. In this modern era, the enormous impact of social media has transformed communication in general and particularly in public relations.

Besides, the trend of coffee products in the international market that has been observed mainly for the consumer over the last of decades is the high level of brand consciousness among consumers behavior. In the global market, the problem of building brand awareness for new brands is not an easy task.

However, the proposed paper targets this issue by providing businesses with optimal methods for creating brand awareness for coffee products from Coffindo Company which called Coffindo Nusantara such as Aceh, Bali, Sumatra, Toraja, and Java. That company was established in 1999 with one vision to become one of Indonesia leading multinational corporation in the coffee industry. Today the company has trade internationally to more than 30 countries with over 17,811 buyers.

In Taiwan, the potential target market is the millennial generation also known as generation Y (people born between ca. 1982 2004). Integrating public relations with marketing reveals the milestone of this phenomenon. It means that in promoting the coffee products to the target market, public relations are not only doing the traditional types of marketing, but are also carrying out any relevant strategies in the public relations domain. The objective of this study is to investigate what kinds of marketing public relations strategies are most suitable to use in Taiwan. 


\section{Literature Review}

\subsection{The Concept of Brand Awareness}

Keller and Davey [7] discussed the challenges and strategies to build brand awareness as the way of ensuring potential customers know the type of products in which the brand competes. They agree on brand awareness as the foundation of their equity model, as all other brand objectives then build on it. Furthermore, brand awareness refers to whether consumers can recall or recognize a name, or only whether or not users know about a brand (Keller, [6]).

Besides, there are different levels of involvement between brand recognition and brand recall. The brand recall could be more likely to require the consumer to expend greater effort to retrieve a name from memory than brand recognition, which only requires customers to determine when the brand is seen or heard previously.

Following these discussions, this study uses the definition of Aaker [1] to assert that brand awareness is a buyer's ability to recognize or recall that a specific brand name is a member of a particular product category. As indicated by Aaker the levels of brand awareness:

(1) Brand acknowledgment: It is the capacity of shoppers to recognize a certain brand among other i.e. "supported review". Supported review is a circumstance whereby an individual is asked to recognize a perceived brand name from a rundown of brands from the same item class.

(2) Brand review: This is a circumstance whereby a buyer is relied upon to name a brand in an item class. It is additionally alluded to as "unaided review" as they are not given any piece of information from the item class.

(3) Top of psyche: This is alluded to as the first brand that a customer can review among a given category of product.

\subsection{Public Relations and Marketing}

Public relations is distinct from marketing in several ways, although their boundaries often overlap. Both disciplines deal with an organization's external relationships and employ similar communication tools to reach the public. Dennis L. Wilcox [3] mentioned the lists eight ways in which public relations activities contribute to fulfilling marketing objectives:

(1) Developing new prospects for new markets, such as people who inquire after seeing or hearing a product release in the news media.

(2) Providing third-party endorsements via newspapers, magazines, radio, and television through news releases about a company's products or services, community involvement, inventions, and new plans.

(3) Generating sales leads, usually through articles in the trade press about new products and services.

(4) Creating an environment for a new product by raising an issue or situation that can be solved through using the new product or service.

(5) Stretching the organization's advertising and promotional dollars through timely and supportive releases about it and its products.

(6) Providing inexpensive sales literature, because articles about the company and its products can be reprinted as informative pieces for prospective customers.

(7) Establishing the corporation as an authoritative source of information on a given product.

(8) Helping to sell minor products that don not have large advertising budgets.

\subsection{Public Relations Strategies}

According to Kirk Hallahan [9] public relations professionals fundamentally operate as frame strategists, who strive to determine how situations, attributes, choices, actions, issues, and the responsibility should be posed to achieve a favorable objective.

On the other hand, a number of techniques can make a message more persuasive [3]. Writers throughout history have emphasized some information while downplaying or omitting other pieces of information. Thus, they address both the content and the structure of messages. Expert communicators continue to use a number of devices, including (1) drama, (2) statistics, (3) surveys and polls, (4) examples, (5) testimonials, (6) endorsements, and (7) emotional appeals.

In addition, a PRWeek [2] survey of marketing executives, for example, found that public relations ranked higher in effectiveness than advertising or marketing in nine areas: (1) brand reputation, (2) corporate reputation, (3) cultivating thought leaders, (4) strategy development, (5) launching a new product, (6) building awareness, (7) generating word of mouth, (8) message development, and (9) overcoming a crisis.

\subsection{The Concept of Marketing Public Relations Strategies}

Kasali [5] defined evidence-based Marketing Public Relations practitioners are involved in many areas of work, such as: (a) Positioning the company as a leader or expert, (b) Building trust (confidence) and consumer loyalty, (c) Introducing new products, (d) Identifying and removing outdated products, (e) Re-launching products, (f) Communicating the benefits of the products, (g) Promoting new methods for using the products that are already known, (h) Building and maintaining a good relationship with people and companies within the producing industry, (i) Reaching secondary markets, (j) regulating trusts and monopolies in order to protect the market, (k) Expanding the use of advertising, (l) Spreading product news prior to advertising, (m) Creating a communicative advertising, (n) Describing the product in more detail, and many more.

However, Ruslan [10] offered marketing public relations practitioner should know about the strategies that what they should do in making a decision or what kind of communication tools to use in realization the program. 
Therefore, the marketing public relations strategies are planning, implementing and evaluating the programs that can stimulate the prospective customer to choose a product. It also can regain the customer satisfaction of prospective customer through the reliable information given and also give positive impression about the products offered which are suitable for their needs, desires, concerns, and interests.

Ruslan [10] in his major study drew attention to distinctive categories several steps in the marketing public relations strategies are:

(a) Conducting market research, to obtain information according to the needs and desires of consumers, in this case, is the prospective consumer.

(b) Creating products. It means a study program by the results of the market research.

(c) Determine the price of these commodities. It means the cost of the coffee products in global market.

(d) Determining the target consumer, target consumer who is suitable for the products.

(e) Planning and implementing promotional campaigns which will be launched and be able to compete in the future and is quite attractive to the prospective consumer.

(f) Maintain good relationships with its stakeholders especially with the customer and government.

\subsection{Marketing Public Relations Tools}

A longitudinal study of marketing public relations tools by Kotler and Kevin [8] have many aspects such as:

(a) Publications: brand awareness will include the expansions of the products based on the publication which will give influence and attract the targeted buyers. These publications such as annual reports per month, brochures, articles, company newspapers, magazines and also audiovisual materials like website or blog about the business.

(b) Identity media: the company needs to create an identity that can be easily recognized by the society or can have media relations to help build brand image and business image. For instance, logo of company or buildings of the enterprise.

(c) Events: the company can make attention to their new products or service by having special events, such as interviews, seminars, exhibitions, competitions, and contests to reach the consumer.

(d) News: One of the main public relations jobs is to make events that fit with the company, and make the media interested in making press releases and coming to the press conferences managed by the corporation.

(e) Speeches: Company will have questions from their costumers and should be able to answer it well.

(f) Public service activities: the company can build a positive image by getting involved in any public service activities.

(g) Sponsorship: the company can market their products by being a sponsor any sports events or cultural events that give the benefit of the enterprise.

\section{Research Aims \& Significance}

The main aims of the study are mention as follows:

(1) Highlight the significance of brand awareness of products and how it can improve their market success rate in Taiwan.

(2) Arrange that a direct relationship exists between brand awareness and marketing public relations strategies.

(3) Characterize alternative tools in marketing public relations that can be used in a more creative and efficient manner to improve brand awareness for new brands among consumers.

The proposed research is significant as not only highlights the importance of brand awareness for new brand penetration in the new market but provides strategies that can be employed by new brands to create knowledge in the marketplace in a more cost effective and efficient manner.

Theory, as well as practical strategies, can be tied to the proposed study using several of case studies with different strategies employed by businesses for rising new brand awareness through various media options.

\section{Methodology}

This study uses a quantitative design survey method to examine the brand awareness of coffee products from Indonesia in an attractive area in Taiwan in the context of Taiwanese. This study use survey method and this study assumed a descriptive research design to gather demographic information from respondent regarding sex, age, the level of education and city of residence.

Further, in this study uses online survey instrument for the purpose of the collection of data for different kinds of the test of the data. In this method, the researcher made an appeal to their respondents to fill questionnaires seriously. Besides, the research methodology of the study is a combination of secondary data and primary data. Secondary data gained from journals, articles, and books using the school library and the internet. The primary data was collected utilizing online surveys to collect the data.

However, the study depends more on the primary data since the research work is about marketing public relations strategies to develop brand awareness coffee products from Indonesia to the international market such as in Taiwan.

Also, in this study uses the online questionnaire as the research instrument for the purpose of the collection of the data by conducting a survey in different areas in Taiwan. All the study selected from other literature regarding, to fit for this research study. This questionnaire contains three parts. These are personal profile, brand awareness, and marketing public relations strategies. In question 1, 2, 3 and four were constructed to know the geographical variables of the respondents.

Furthermore, for brand awareness of the coffee products from Coffindo Company, two of brand awareness attributes such as first of mind, and brand recognition adopt from past research Kapferer [4]. The questionnaire from part two until 
part three used the Likert scale for the respondents to select only one option from five items. All the questions designed in the English language.

In this research, the questionnaire was one of the methods applied in the collection of data or information about the consumer. However, the correspondents have limitations experienced in the use of surveys in an English version. For instance, the questionnaire used in the English version, which most of the respondents using Chinese. The target is composed of clients from diverse backgrounds in Taiwan.

Further, most of the correspondents use English as their second language there is probability they did not understand the questions well posted to complete, and this was not enough to gather sufficient information. Disseminating the issues and analyzing the responses required substantial time to understand the products coffee from Indonesia.

In addition, according to Saunders and Thornhill [11], it is not easy to tell how truthful the clients are when giving their suggestions. It noticed that some respondents did not submit their questionnaires after answering the questions. It is because some people were not willing to offer their opinions or fill in the questionnaires.

\section{Results}

The most striking result to emerge from the data there was 115 correspondents completed and returned the online questionnaire. The results indicate that coffee consumption is growing strongly throughout Taiwanese, from the product of this research found that $80 \%$ Taiwanese they are like to drink coffee. Furthermore, this correlation is related to they answer usually drink coffee $1-3$ cups a week is about $48.7 \%, 3-5$ cups $25.2 \%$ and 5 or more cups $26.1 \%$.

However, over half of those surveyed reported that in the question regarding brand awareness, the result shows that precisely $51.3 \%$ of Taiwanese they know about coffee from Indonesia, only $37.4 \%$ who do not know, and $11.3 \%$ who not sure. Also, the percentage of Taiwanese who have experience drink Indonesian coffee is about $40 \% .38 .3 \%$ they do not have a drink, and $21.7 \%$ they not sure. Most of the coffee is sold through several places, as shown in Table 1.

Table 1. Coffee Stores Q26.

\begin{tabular}{ll}
\hline Places & Percentages \\
\hline Coffee Bars & $65.20 \%$ \\
Coffee Kiosks & $27.80 \%$ \\
Restaurants & $26.10 \%$ \\
Vending Machine & $35.70 \%$ \\
Other & $11.30 \%$ \\
\hline
\end{tabular}

It is apparent from Table 2 indicates that most of Taiwanese about $82.60 \%$ they are use technology such as internet and social media to find more information about coffee products. Also, it is clear that the second largest number from advertisement about $43.50 \%$. Surprisingly, from book or magazine only more higher than exhibition around $1 \%$.
Table 2. Media to find information Q27.

\begin{tabular}{ll}
\hline Places & Percentages \\
\hline Internet or Social Media & $82.60 \%$ \\
Book or Magazine & $21.70 \%$ \\
Advertisement & $43.50 \%$ \\
Exhibition & $20.80 \%$ \\
Other & $2.60 \%$ \\
\hline
\end{tabular}

Overall, the results indicate a several difference between Male and Female opinion regarding the coffee products from Indonesia, in case Coffindo Company products. Table 3 provides a closer at between Male and Female who interested in the products of coffee. It can be seen from mean Male is slightly higher than Female and from Standard Deviation is clear that the number of Male more than Female.

Table 3. Descriptive information.

\begin{tabular}{lllll}
\hline & Gender & N & Mean & Std. Deviation \\
\hline \multirow{2}{*}{ Q14 } & Male & 48 & 4 & 1.052 \\
& Female & 67 & 3.85 & 0.875 \\
Q15 & Male & 48 & 2.75 & 1.212 \\
& Female & 67 & 2.82 & 1.205 \\
Q16 & Male & 48 & 2.58 & 1.2 \\
& Female & 67 & 2.34 & 1.2 \\
Q17 & Male & 48 & 3.9 & 0.951 \\
Q18 & Female & 67 & 3.6 & 1.001 \\
& Male & 48 & 3.71 & 1.051 \\
Q19 & Female & 67 & 3.47 & 0.731 \\
& Male & 48 & 3.13 & 0.64 \\
Q20 & Female & 67 & 3.1 & 0.581 \\
& Male & 48 & 3 & 0.744 \\
Q21 & Female & 67 & 2.94 & 0.868 \\
& Male & 48 & 2.56 & 0.92 \\
Q25 & Female & 67 & 2.28 & 1.126 \\
& Male & 48 & 3.56 & 1.09 \\
\hline
\end{tabular}

The single most striking observation to emerge after comparing the data was scores between the $t$-test results, shown in Table 4 below did not reach statistical significance between Male and Female they are interested in those coffee products from Coffindo Company if those coffee products are available in Taiwan. Evaluating the result reveals from several questions indicates that is a potential market for coffee products from Indonesia.

The correlation between Male and Female remarkable because from 115 correspondents felt that they need to know the coffee products before they drink or buy. Nearly half of respondents (48\%) agreed that it is important to know the products before consuming it. Data from this table can be compared with the data from Table 2, showing that the consumers tend to find Information before decided to buy the products.

A further statistical test revealed a positive correlation between Male and Female in five different products Coffee Nusantara from Coffindo Company. The correspondents can memorize the different apparent from those products quickly because every single of coffee products represent the local culture. Only a small number of respondents indicates that difficult to remember the differences between the products. 
Table 4. Independent Samples Test.

\begin{tabular}{|c|c|c|c|c|c|c|}
\hline \multirow{2}{*}{$\begin{array}{l}\text { Equal variances assumed } \\
\text { Equal variances not assumed }\end{array}$} & \multicolumn{2}{|c|}{ Levene's Test for Equality of Variances } & \multicolumn{2}{|c|}{$t$-test for Equality of Means } & \multirow[b]{2}{*}{ Sig. 2-tailed } & \multirow[b]{2}{*}{ Mean. Difference } \\
\hline & $\mathbf{F}$ & Sig. & $\mathrm{t}$ & Df & & \\
\hline \multirow[t]{2}{*}{ Q14 } & 0.161 & 0.689 & 0.829 & 113 & 0.409 & 0.149 \\
\hline & & & 0.804 & 89.475 & 0.424 & 0.149 \\
\hline \multirow[t]{2}{*}{ Q15 } & 0.006 & 0.938 & -0.31 & 113 & 0.757 & -0.071 \\
\hline & & & -0.31 & 101.074 & 0.757 & -0.071 \\
\hline \multirow[t]{2}{*}{ Q16 } & 0 & 0.993 & 1.058 & 113 & 0.292 & 0.24 \\
\hline & & & 1.058 & 101.43 & 0.293 & 0.24 \\
\hline \multirow[t]{2}{*}{ Q17 } & 0.611 & 0.436 & 1.612 & 113 & 0.11 & 0.299 \\
\hline & & & 1.626 & 104.401 & 0.107 & 0.299 \\
\hline \multirow[t]{2}{*}{ Q18 } & 8.094 & 0.005 & 1.398 & 104 & 0.165 & 0.243 \\
\hline & & & 1.353 & 81.382 & 0.18 & 0.243 \\
\hline \multirow[t]{2}{*}{ Q19 } & 0.264 & 0.609 & 0.179 & 113 & 0.858 & 0.021 \\
\hline & & & 0.176 & 95.227 & 0.861 & 0.021 \\
\hline \multirow[t]{2}{*}{ Q20 } & 1.193 & 0.277 & 0.386 & 113 & 0.701 & 0.06 \\
\hline & & & 0.396 & 109.351 & 0.693 & 0.06 \\
\hline \multirow[t]{2}{*}{ Q21 } & 2.109 & 0.149 & 1.411 & 113 & 0.161 & 0.279 \\
\hline & & & 1.459 & 110.96 & 0.147 & 0.279 \\
\hline \multirow[t]{2}{*}{ Q25 } & 0.034 & 0.854 & -0.022 & 113 & 0.982 & -0.005 \\
\hline & & & -0.023 & 102.189 & 0.982 & -0.005 \\
\hline
\end{tabular}

As can be seen from table 5, further analysis showed that did not reach statistical significance number between Male and Female from 3 different questions that indicates it is good to have free coffee machine in Bank, Library Campus, and Bus, MRT or Train Station. Turning now to the experimental evidence can be seen from mean Male is fewer than Female and from Standard Deviation is clear that the number of Male do not have significant different with Female.

Table 5. Descriptive information.

\begin{tabular}{lllll}
\hline & $\begin{array}{l}\text { Mean } \\
\text { (Total) }\end{array}$ & $\begin{array}{l}\text { Std. } \\
\text { Deviation }\end{array}$ & $\begin{array}{l}\text { Mean } \\
\text { (Male) }\end{array}$ & $\begin{array}{l}\text { Mean } \\
\text { (Female) }\end{array}$ \\
\hline Q22 & 2.2 & 1.077 & 1.916 & 2.402 \\
Q23 & 2.113 & 1.152 & 1.958 & 2.223 \\
Q24 & 2.347 & 1.132 & 2.125 & 2.507 \\
\hline
\end{tabular}

\section{Conclusion}

Based on data analysis there are several generalizations indicated the marketing public relations strategies to develop brand awareness of coffee products from Indonesia such Coffindo Nusantara in Taiwan. Contrary to expectations, this study did not find significant different between Male and Female in order to buy a coffee products. However, this study derived other possible explanations.

The comparison of coffee products should recognize as the other possibility that is could attract the consumers, using tools from marketing public relations such as publications, identity media, evens, news, speeches, public service activities, and sponsorship. Furthermore, most of the participants in this study are students that mean they live nearby campus. An Impact of the result can source new market in Taiwan in several cities. However, the impact should have one possible explanation for this result is that the target market should focus on generations millennial.

Thus, in practice of public relations practitioners has the skill to make the proper strategies on the internet, such as website, blog and social media or even build the good image in media relations to increase brand awareness in the international market. Also, the technology now is developing rapidly, and social media at the moment is the powerful weapon to promote brand awareness because it has a potential number of people. A destination brand should in a variety of ways.

The other way of explaining this result is that consumers while making purchase intention are not highly involved in the brand itself and are more concerned with the products usage, while only brand Coffindo Nusantara in this case, which proves an exception to this rule may result from longevity of its advertising.

Therefore, the paper draw a generalize conclusion from this conception and suggest that in brands where the product is low involvement and considered a commodity; awareness of a brand may not constitute a significant factor for purchase behavior. Further, such purchases are normally made by servants and as such coffee is brought and not a brand. This is similar to the production concept in the marketing literature where consumers are more interested in the product than its features.

In the end, for the future research should aim to explore the relationship with the lifestyle generation millennial from another countries to determine the international business for coffee products from Indonesia, because there is still possibility to expand the target market to another countries. In future investigations, it might be possible to use different coffee products in which variant, but still consider about improving brand awareness using public relations strategies as the tools to inform the consumers.

\section{Acknowledgements}

This research supported by the Ministry of Research, Technology and Higher Education of the Republic of 
Indonesia. The author would like to thank the referees for their kind and helpful comments.

\section{References}

[1] Aaker, David. Managing Brand Equity. Capitalizing on the Value of a Brand Name. The Free Press: New York, 1991.

[2] Ashooh, N. Master Class: How must education evolve to address the PR professional's expanding role? PRWeek, 51-52. 2012.

[3] Dennis L. Wilcox, Glen T. Cameron, and Bryan H. Reber, Public Relations Strategies and Tactics. $11^{\text {th }}$ editions. Pearson Education: London, 2015.

[4] Kapferer, J. N. Strategic brand management. The Free Press: New York, 1994.

[5] Kasali, Rhenald. Manajemen Public Relations. Konsep dan Aplikasinya di Indonesia. Pustaka Utama Grafiti: Jakarta, 2005.
[6] Keller K. L. Strategic Branding Management. Building, Measuring, and Managing Brand Equity. 3rd ed. Upper Saddle River, New Jersey: Prentice Hall, 2008.

[7] Keller, K. L. and Davey, K.K. Building Customer Based Brand Equity. Advertising Research Foundation Workshop: New York, 2001.

[8] Kotler, Philip., and Kevin L. K. Manajemen Pemasaran, $12^{\text {th }}$ editions. Indeks: Indonesia, 2007.

[9] Lecheler, S. and de Vreese, C. H. News framing and public opinion: A mediation analysis of framing effectson political attitudes. Journalism and Mass Communication Quarterly, 89(2), 185-204. 2012.

[10] Ruslan, Rosady. Manajemen Public Relations dan Media Komunikasi: Konsepsi dan Aplikasi, Raja Grafindo Persada: Jakarta, 2006.

[11] Saunders, Lewis., and Thornhill. Research Methods For Business Students. Harlow: Financial Times Prentice- Hall Inc, 2000. 